\title{
VIBEKE TUXEN
}

\section{KUNAERNE KÆEMPER - MED MYTE OG METAFOR}

Det var Duiren, der oprindeligt lærte kunaindianerne at kæmpe. I tidernes morgen flygtede hans bedsteforældre med ham, mens han var et lille barn, og deres folk blev slået ihjel. Kunaerne gjorde ikke modstand, de vidste endnu ikke hvad kamp var. Bedsteforældrene opfostrede ham og opdrog ham, og de var de eneste mennesker dér. De fortalte ham ingenting om deres flugt. Da han blev gammmel nok, spurgte han sine bedsteforældre, hvordan det kunne være, at der ikke var en masse mennesker som de. „Der findes ikke andre end os“, var det svar han fik. Men Duiren insisterede: „Hvordan kan det da være, at der er så mange bakker, så mange træer, alle de rige floder, så mange bække?“ Da forstod de, at han måtte have et svar, og de fortalte ham om, hvordan menneskene blev slået ihjel, og de selv var flygtet op i bjergene. Fra den dag besluttede Duiren sig for at vende tilbage og kæmpe for sit folk. Den dag opfandt Duiren begrebet modstand, og han lærte sine frænder at kæmpe for, hvad de har kært.

Og det har kunaerne gjort lige siden. De lever i Panama og var selv med til at bestemme, at deres område kom under Panama, dengang landet i 1903 løsrev sig fra Columbia. Europæerne drev i 1700-tallet kunaerne fra Columbia og nordpå til det, der nu er Panama, over bjergene og ud til kysten, ud på øerne, hvor langt de fleste nu bor på koraløer langs kysten. Hertil og ikke længere, besluttede kunaerne, og i 1925 havde de kæmpet sig til selvstyre i reservatet San Blas, som de selv kalder Kuna Yala. Det ligger langs hele den nordøstlige kyst af Panama. Siden fik kunaerne en særaftale med USA's regering om, at først og fremmest kunaerne fik de job, der ville blive i kanalzonen.

\section{Kunaerne i Wargandi}

Men der var nogle kunaer, der ikke fulgte med over bjergene. De blev i skoven på sydsiden af bjergene, og der bor de endnu. Wargandi kaldte de området. De valgte at fastholde og styrke deres kunatilværelse og samtidig inkorporere elementer fra den panamanske verden som for eksempel stof til deres uvurderlige molas, bluserne som kvinderne syr efter specielle teknikker, mønstre og farver. Men i 1977 førte staten den panamerikanske hovedvej længere ned mod Columbia, og derved kom der både panamanske tømmerfolk og nybyggere til området. I dag er grænsen til reservatet ganske tydelig, for der er skov på 
indianernes side og græs på nybyggernes. Ikke fordi kunaerne altid beskytter deres skov, men for dem er dette udkanten, hvor den vilde skov ligger, mens de selv bor i centrum. Naturligvis.

Nu arbejder kunaerne i Wargandi for at bevare deres område. De har prøvet selv at få råderet over deres territorium under Panama siden 1952, men nu har de måttet søge hjælp udefra, fra fremmede, i deres bestræbelser. Og det er ikke nemt, når man er kuna og har så mange dårlige erfaringer med fremmedes indtrængen. En kunaorganisation i Panama City, Fundación Dobbo Yala, og Regnskovsgruppen Nepenthes fra Danmark er gået sammen om at støtte kunaerne i Wargandi i arbejdet for deres territorium. Det er Danida, der finansierer projektet. Grænsen skal opmåles og markeres, samtidig med at kunaerne lærer både at løse konflikter med nybyggerne og om indfødte folks rettigheder nationalt og internationalt. De skal lære selv at arbejde for deres rettigheder over for den panamanske stat. Og de ønsker at lære. Tre gange uafhængigt af hinanden på samme rejse har jeg fået myten om Duiren fortalt. Den er højaktuel. Det er i denne virkelighed, at jeg som projektkoordinator fra Danmark nu dumper ned og får et lille indblik i kunaernes univers og forholden sig til det, der kommer udefra.

\section{Landsbyens kerne}

En kunalandsbys fælleshus er kernen for landsbyens fællesskab og viden. Ibeorgun, en mytisk figur, ankom til denne verden og lærte for første gang kunaerne at bygge fælleshuse og at bruge huset til at bringe viden videre fra menneske til menneske og fra generation til generation. Han udvalgte træerne, som skulle bruges til huset, og gav hver pæl og hver bjælke i huset navn. Ibeorgun lærte kunaerne det, der gjorde dem til kunaer frem for alle andre folk. Han gav dem viden og lærte dem om naturens betydning og hvordan, den kan beherskes (López Hernández 1990)

Hver aften mødes landsbyens borgere nu i fælleshuset for at diskutere dagen, der gik, og lytte til høvdingenes ord over både historiske og mytiske temaer og dagsaktuelle begivenheder. Sidst på eftermiddagen er en mand (suaribed) gået rundt $\mathrm{i}$ byen med sin stav for at indkalde til aftenmødet og fortælle, hvad aftenens tema er, og hvem der synger eller fortæller. Ud fra dette beslutter hver især, om de vil komme til aftenseancen netop i dag. Der er nogle høvdinge, de store fortællere, der næsten altid trækker fuldt hus. I landsbyen Wala i Wargandi, som måske har 900 indbyggere, er der 14 høvdinge med hver deres ansvarsområde inden for landsbyen. Det er flere høvdinge end de fleste byer har. Disse aftener er filosofi i praksis. Først når myterne bliver udtalt, får de betydning, og tilhørerne er lige så vigtige som fortælleren. Høvdingen kender sine myter, men i praksis er fortællingen afhængig af dagsaktuelle emner. For at blive en leder af betydning er det ikke nok at kende myterne, man skal også kende sin landsby, dens folk, dens historie og dens nutid (López Hernandez 1990).

\section{Problemet}

Kunaerne i Wargandi befinder sig i et dilemma af dimensioner. De kæmper for deres kultur, som den er og var, men er nødt til at inddrage støtte fra den verden, de ikke ønsker 
skal blive deres fremtid. De er tvunget til at lære denne anden verden at kende for at kunne arbejde på dens betingelser, men de har også set, hvad den kan gøre ved indfødte folk, hvis først den får sit tag i dem. De må søge at forstå og analysere denne anden verden ud fra deres egne begreber og eget verdensbillede. Myterne bliver det middel, der binder det hele sammen.

Det aftenmøde, der her vil blive beskrevet, finder sted, fordi de fremmede er kommet for at diskutere og igangsætte projektet til opmærkning af Wargandi-reservatet. De fremmede er tre kunaer fra Fundación Dobbo Yala og en fra Nepenthes i Danmark, nemlig undertegnede. Det er i disse dage, at projektets ærlighed skal stå sin prøve. Vi har mødt hinanden før, men det var for to år siden, dengang ingen vidste, om dette ville blive til noget. Hvad siger danskeren om projektet, og stemmer det overens med, hvad der hidtil er blevet sagt. Hvad er mon hendes motiver for at arbejde her, så fjernt fra hjemmet?

Kunaerne skal tage stilling til deres egen fremtid - og dermed fortid. Hvad vil de, hvem er de? Hvem er vi, de fremmede, og hvad vil vi? Har vi en verden til fælles eller er der en verden til forskel? Hvem udnytter hvem, og hvordan kan kunaerne få mest ud af det? Kan verdenerne støtte hinanden uden at noget går tabt? Og hvordan forbliver kunaerne herre over deres egen tilværelse? Det er denne analyse af fremtiden, dens muligheder og problemer, kunaerne skal igennem. En offentlig analyse, for det er alles anliggende, og først når myter bliver udtalte i et samspil mellem flere personer, får de mening og bliver virkelige for kunaerne.

Aftenmødet denne 16. august 1996 er indledningen til et to-dages møde mellem Wargandis tre landsbyer. Der er mange mennesker til stede i fælleshuset. Næste morgen skal starte med en diskussion af selve projektet. Den her beskrevne tale eller sang af Høvding (saila) Horacio Turiño blev optaget på bånd, skrevet ned på kuna og derefter løst oversat til spansk af Aurelio Chiari. Selv fik jeg den simultantolket, imens den blev holdt.

\section{Aftenmødet}

Høvding Horacio Turiño, den øverste høvding i Wala, åbner aftenmødet med at synge over temaet: Hvem er disse fremmede, der siger, de kommer for at støtte os. Hvorfor gør de det, hvad vil de opnå? Han synger i høvdingenes arkaiske og metaforiske sprog, som hovedparten af tilhørerne ikke forstår. Han synger i en ensartet melodi, hvor hver sætning starter højt for derefter at ende dybt og næsten uhørligt. En anden høvding svarer med sit langtrukne ,eeeeeeee“ som glider ind og ebber ud efter hver sætning. (Det er sandsynligvis ordet „teki“, som Sherzer (1989:265) nævner, at kunaerne bruger i Kuna Yala, og som betyder ,sådan er det“, men mit utrænede øre opfatter kun ,eee“. Resten forsvinder i dunkelheden.) De sidder ved siden af hinanden overskrævs i hver sin hængekøje midt i fælleshuset og stirrer lige frem for sig. Hverken tonefald eller øjne fortæller, hvad der synges om; det er ordene, det gælder. Sangen er lang, 1 1/2 time, og et par mænd råber jævnligt til tilhørerne: „Fald nu ikke i søvn“ og ,lyt til de vise ord“.

Kunaere er et folk af ordet. Evnen til at være en god taler er højt værdsat, om det så er i almindelig, dagligdags tale, høvdingenes sange eller den rituelle sang og tale (Sherzer 1989:263). Ved ordet genskabes myterne, de får ny betydning i forhold til dagens aktuelle emner, og de bevarer samtidig tilknytningen til fortiden og en verden, der hænger sammen i tid og rum. Kunaernes myter er aktive; ved brugen og fortællingen får de liv og 
betydning. Sangen kaldes på kuna igar, hvilket betyder sti, både den rent fysiske og den, der i overført betydning fører mennesket fra et sted til et andet. Sangen skal lede folket frem (López Hernández 1990:16; Sherzer 1989:264).

Når høvdingen har sunget, overtager tolken (argar). Han ikke blot oversætter, men tolker høvdingens ord på kunaernes daglige sprog og altid i forhold til det aktuelle emne, som høvdingens sang er en kommentar til. Hvad blev der sunget, og hvad vil høvdingen sige til forsamlingen med disse ord. Tolkningen bliver talt og ikke sunget, der er ikke de samme billeder i talen, og den er kortere end sangen. Også tolken stirrer stift ud i luften, mens han taler. Det er først nu, hovedparten af tilhørerne forstår, hvad der bliver sagt. I begyndelsen af aftenen er der en masse larm fra børnene, der løber omkring og leger, mens kvinder snakker sammen, og folk kommer og går. Larmen hører til, og når børnene falder til ro på deres madrasser og tæpper med hinanden i armene, falder der ro over foretagendet. Måske er det derfor, indledningerne ofte er meget lange i høvdingenes taler.

\section{Høvdingens sang}

Ved aftentide i dag har mændene [suaribgan] kaldt os sammen for at vi skulle mødes i Guds [Babas] hus og således udfylde en mission, som han har betroet os....

Eeeeee....

... Da han lod os blive tilbage på jordens overflade forberedte han os på, at vi hans sønner, Olodule [menneskene af guldet], altid skulle blive invaderet og presset af elementer udefra, som ikke er kunaer.

Eeeeee...

Sangen svinger frem og tilbage imellem fortid, nutid, hvorfor menneskene er her på jorden, og hvorfor vi er her $\mathrm{i}$ aften, her i Ibeorguns hus.
Vi lever i en usikker verden, hvor vi hele tiden føler os mere presset. Vi kender værdien og betydningen af vores Moder Jord, og vi er derfor bekymrede for den fare, der lurer over hende. Efter at vores forfædre forlod denne verden, kæmper vi for at bevare vores kultur og vores territoriums nedarvede historie. Situationen bliver hele tiden sværere.

Sætningerne er korte med en enkelt meddelelse i hver og med mange gentagelser, hvor måske blot et enkelt ord ændres i forhold til sidste sætning. Langsomt bygges indholdet op (jf. ,grammatical parallelism“, Sherzer 1989). Sangen fortsætter med at nævne disse mennesker „,brødre kunaer og fra et andet kontinent“", som er kommet for at støtte, og håber, at de mener det ærligt og ikke vil snyde. For det har vist sig, at vi (kunaerne) ikke kender deres tanker. Man kan aldrig se, hvad der foregår inde i mennesker. Høvding Horacio har hørt om gode jagthunde, der kender deres pligt og straks bringer byttet til deres herre. Men han har også hørt, at der findes andre jagthunde, dårlige jagthunde, som i stedet for at bringe byttet til deres herre bliver ved det og spiser det. Han ved ikke, hvem disse fremmede er, men der findes gode og dårlige mennesker blandt os alle, og ikke alle fremmede er dårlige mennesker. Han må håbe, at disse fremmede vil kunaerne det godt.

Også Duiren måtte søge hjælp udefra, da han kæmpede for sit folk. Vi kan også være afhængige af en sådan hjælp.

Vi lever nu i en verden, hvor vores territorium står i fare for at blive invaderet af nybyggere. Hvis vi havde levet i rolige omgivelser, havde vi ikke tænkt på at udvikle et projekt af den- 
ne art. Vi står over for den ubestridelige kendsgerning, at mennesker fra en anden kultur vil blande sig i vores verden... Vi ønsker fortsat at leve i fred og udvikle vores kultur som en arv fra vores forfædre og vores fortid.

Nu håber vi, at vi denne gang når vores mål... Vi kan nu blot håbe og arbejde, hertil rækker mine ord, nu afventer vi tolkens mellemkomst.

\section{Myten, metaforen, kunaerne og det fremmede}

Jeg genkender hele forløbet fra Joel Sherzers artikel „Namakke, Sunmakke, Kormakke: Three Types of Cuna Speach Event" (1989), hvori høvdingenes sang over historiske, religiøse eller dagsaktuelle politiske emner beskrives detaljeret og sammenlignes med to andre former for tale/sang, nemlig ved helbredelser og ved pigernes pubertetsriter. Høvdingenes sange er levende og varierede på samme måde, som det politiske indhold er levende og skiftende. Ved helbredelsens og riternes taler er det anderledes, her gælder det tværtimod om at være så ordret korrekt som muligt, således som talen er blevet holdt siden tidernes morgen (op.cit.:282).

Jeg er dumpet ned i en uendelig historie af myter, et sted mellem fortid, nutid og fremtid eller i det hele på en gang. Her er hverken lige linie frem eller tilbage. Når Duiren lærer kunaerne at kæmpe, gør han det igen og igen, hver gang myten bliver fortalt eller der bliver henvist til den. Myten kæder nutiden sammen med fortiden; det er den samme myte, og samtidig er den ny hver gang, den fortælles i en ny virkelighed. Og den kaster nyt lys på den virkelighed, der leves. Jeg, den fremmede, er den hjælp, Duiren søger udefra for at støtte sit folk, og jeg kan være den hjælp, kunaerne behøver for at få deres territorium anerkendt. Myter er fleksible, de lukker omverdenen og nye elementer ind eller holder dem ude efter aktuelle behov. De forarbejder omverdenen, og de påvirkes selv af den, hver gang de bliver fortalt. Lederen af projektet, som er kuna, har skrevet en artikel om menneskerettigheder og indfødte folks rettigheder set fra kunaernes synsvinkel (López Hernández 1997). Når han citerer tidligere tiders store høvdinge, gør han det i datid, men myter gengives i nutid. Myter er allestedsnærværende, uden for tid og rum, uden grænser.

Jeg oplever, hvordan de myter, der i vores verdens beskrivelser fortælles og analyseres som en samling af enkeltfortællinger (så de passer ind i bogens form), i virkeligheden hænger sammen i én stor fortælling, de er vævet ind i hinanden til en stor sammenhængende, uendelig historie. Når en myte fortælles, begynder kunaen nogle gange her, nogle gange der, måske et sted som også var en del af en anden fortælling, som jeg fik fortalt forleden dag af en helt anden person. Det afhænger af konteksten, hvor en myte begynder, hvilken vej den tager, og hvor den stopper; det afhænger af, hvad det er, man vil sige med den. Således danner myternes helhed den baggrund, kunaerne ser og opfatter verden med, men samtidig udvælges den myte, man vil fortælle, dens begyndelse og afslutning, ud fra, hvad man har på hjerte og hvilken holding eller fortolkning, man vil bringe videre. Ved at blive set på med hele dette univers af myters øjne, bliver jeg en del af deres verden, lukket ind til deres forståelse. Og samtidig udvælges de specifikke myter, jeg bliver tolket med, ud fra den skepsis, kunaerne har lært af århundreders sam- og modspil med den hvide mand. Både i forhold til kampen for at forblive kunaer, i forhold til en stærk skepsis mod de hvide og i forhold til afhængigheden af støtte udefra, passer jeg ind i den verden, som Duiren levede med. Derfor bliver netop den myte trukket frem. 
Metaforen om jagthundene bliver brugt til at vise den generelt stærke skepsis mod hvide mennesker, men samtidig bliver den brugt til at vise, at de hvide også er mennesker med samme forskelligheder som andre mennesker, det vil sige kunaerne. Muligheden for at have tillid til mig som menneske bliver trukket frem. Metaforer er karakteristiske for høvdingenes sange ved aftenmøderne. Sherzer nævner som eksempel, at kvinder generelt beskrives som blomster, og blomster, der har egenskaber svarende til det, man gerne vil sige om kvinder i denne tale, kan trækkes frem. Og høvdinge sammenlignes med bærende stolper i fælleshuset (Sherzer 1989: 279). Metaforer er åbne for fortolkning, de kan sommetider føres ud til at beskrive længere forløb, og det er tolkens opgave at gennemføre denne fortolkning, så tilhørerne forstår pointen. Gode metaforer er et af den gode talers vigtige virkemidler.

Der er andre måder, hvorpå jeg som fremmed bliver lukket ind i kunaernes univers. En lille pige har nu fået mit navn, selvom det er svært at udtale for kunaerne. Allerede før kunaerne i Wargandi lærte mig at kende, havde jeg fået at vide, at det nok ville ske. Og jeg har selv fået mit kunanavn. Blandt andet ved at give navne forholder kunaerne sig til den omgivende verden, og mange kunaer har navn efter mennesker rundt om i verden. Jeg har således en aften talt længe med Lyndon B. Johnson (Johnson er også mærket på en påhængsmotor, hvorfor en anden kuna siden har fået navnet Yamaha!). Men jeg ved også, at hvis den person, en kuna er blevet navngivet efter, falder i unåde, eller kunaen bare bliver træt af sit navn, skifter han det ud med et andet. Og personen er dermed ude af kunaernes verden igen. På samme måde afbilder molaerne nye temaer i hverdagen, men i kunaernes egen stil, og når man bliver træt af en mola, bliver den solgt til panamanere eller turister. Jeg har set både Mickey Mouse og julemanden til salg. Og en kunakvinde syr netop nu på en mola med motivet fra en Nepenthes t-shirt. Denne fleksibilitet til at inkorporere nye emner i hverdagen med indbygget mulighed for fortolkning og for at lukke dem ud igen, ved myter, navne eller molaer, er således en del af kunaernes virkemidler til at kunne forholde sig til den omgivende verden og samtidig forblive sig selv

Kunaerne tog efter aftenmødet imod støtten udefra, og jeg måtte skrive under på, at jeg hverken vil påføre dem min kultur, fælde deres træer eller tage deres guld. Således kom der nogle særdeles konkrete resultater ud af situationsanalysen. Med myten, metaforen og den sunde fornuft besluttede kunaerne, hvilke dele af verden udenfor, der skulle lukkes ind, og hvilke der skulle holdes ude.

\section{Litteratur}

López Hernández, Heráclio

1990 Aproximación a la Sabiduría GUNGIDULE. Universidad Pontificia Bolivariana, Facultad de Filosofía, Medellin, Colombia. (Upubliceret).

1997 Menneskeret, indfødte folks ret. Skov \& Folk 3. København: Regnskovsgruppen Nepenthes. (Under udgivelse).

Sherzer, Joel

1989

Namakke, Sunmakke, Kormakke: Three Types of Cuna Speach Event. I: Richard Bauman \& Joel Sherzer (eds.): Explorations in the Ethnography of Speaking. Cambridge.

Tuxen, Vibeke

1996 Nepenthes trækker grænsen. Skov \& Folk 4. København: Regnskovsgruppen Nepenthes. 